\title{
Esophageal Impaction: A Rare Complication of Tissue Glue Injection for Gastric Variceal Bleeding
}

A 69-year-old woman had a history of liver cirrhosis related to chronic hepatitis C. She underwent endoscopic ligation for esophageal variceal bleeding in February 1996, and injection of endoscopic tissue glue (a mixture of $0.5 \mathrm{ml} \mathrm{N}$-butyl-2-cyanoacrylate with $0.5 \mathrm{ml}$ Lipiodol) for gastric variceal bleeding in November 1998. Gastric variceal hemorrhage recurred in December 1999. An emergency endoscopic tissue glue injection was performed, and the bleeding stopped immediately. Another two injections were given to eradicate the residual gastric varices. However, the mixture of the last injection extruded immediately. Because the bleeding stopped, the endoscope was removed.

The patient complained of dysphagia soon after the tissue glue injection, and administration of acetaminophen or prokinetic agents did not relieve this. A follow-up endoscopy revealed an extrusion of tissue glue that had formed a foreign body trapped in and occluding the lower esophagus (Figure 1). Dysphagia resolved immediately after endoscopic removal of the tissue glue using a Dormia basket.

Variceal injection of tissue glue has been more effective than conventional sclerosants in the treatment of acute gastric variceal bleeding [1]. A major drawback of tissue glue injections has been damage to equipment and injury to operators [2]. Undesired local side effects include retrosternal pain, pyrexia, and ulceration [3]. Other rare severe complications are related to systemic emboli [4]. Extrusion of the tissue-glue foreign body from the necrotic gastric mucosa usually occurs after several weeks of treatment [1]. Immediate leakage

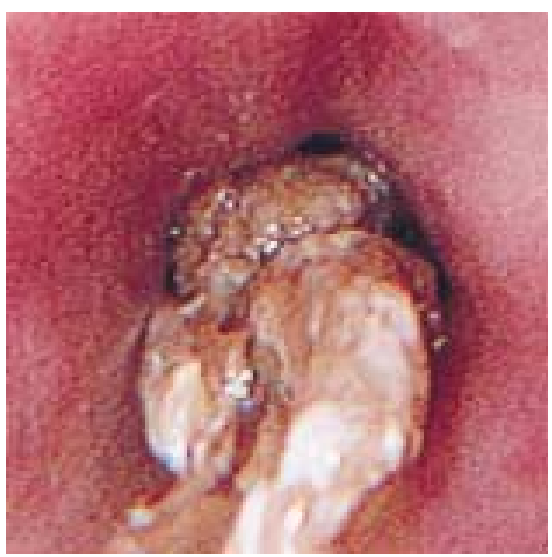

Figure 1 The endoscopic image shows a firm foreign body (tissue glue) trapped in the lower esophagus of the tissue glue may occur when it is injected into the thrombosed varices. In the present case, it is possible that retching or vomiting during the endoscopy may suddenly have increased the intra-abdominal pressure and forcefully expelled the foreign body into the esophageal lumen.

If dysphagia occurs after tissue glue injection for gastric variceal bleeding, esophageal impaction of the tissue glue should be considered. If this happens, the foreign body can be removed using an endoscopic Dormia basket.

T. T. Liu, M. C. Hou, H. C. Lin,

F. Y. Chang, S. D. Lee

Division of Gastroenterology,

Dept. of Medicine, Taipei Veterans'

General Hospital, and National Yang Ming

University School of Medicine, Taipei,

Taiwan

\section{References}

${ }^{1}$ Soehendra N, Grimm H, Nam VC, et al. $\mathrm{N}$-butyl-2-cyanoacrylate: a supplement to endoscopic sclerotherapy. Endoscopy 1987; 19: 221-224
${ }^{2}$ Binmoeller KF, Soehendra N. "Superglue": the answer to variceal bleeding and fundal varices? Endoscopy 1995; 27: $392-396$

${ }^{3}$ Feretis C, Tabakopoulos D, Benakis P, et al. Endoscopic hemostasis of esophageal and gastric variceal bleeding with Histoacryl. Endoscopy 1990; 22: 282-284

${ }^{4}$ Palejwala AA, Smart HL, Hughes M. Multiple pulmonary glue emboli following gastric variceal obliteration. Endoscopy $2000 ; 32$ : S1-S2

Corresponding Author

M. C. Hou, M.D.

Division of Gastroenterology

Dept. of Medicine

Veterans' General Hospital

No. 201, Sect. 2

Shih-Pai Road

Taipei 11217

Taiwan

Fax: $\quad+886-2-2873-9318$

E-mail: mchou@vghtpe.gov.tw 